\title{
SEED PRIMING WITH ZINC MODULATE GROWTH, PIGMENTS AND YIELD OF CHICKPEA (Cicer arietinum L.) UNDER WATER DEFICIT CONDITIONS
}

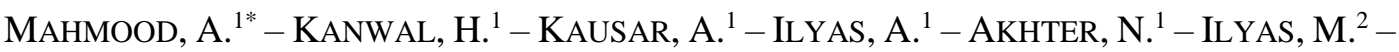 \\ NISA, Z. ${ }^{1}-$ KHALID, H. ${ }^{1}$ \\ ${ }^{I}$ Department of Botany, GC Women University \\ Arfa Kareem Road, Block Z Madina Town, Faisalabad City, Punjab Province, Pakistan \\ ${ }^{2}$ Department of Home Economics, GC Women University \\ Arfa Kareem Road, Block Z Madina Town, Faisalabad City, Punjab Province, Pakistan \\ *Corresponding author \\ e-mail: ammaramahmood772@yahoo.com; phone: +92-334-744-4522
}

(Received $19^{\text {th }}$ May 2018; accepted $31^{\text {st }}$ Jul 2018)

\begin{abstract}
The research was conducted to assess the role of pre-sowing seed treatment with $0.05 \% \mathrm{ZnSO}_{4}$ solution on four varieties of chickpea (Cicer arietinum L.) i.e. CM 2008, FG 0902, DO 75-09 and Pb 2008 under three different drought conditions. Seeds primed with distilled water and $0.05 \% \mathrm{ZnSO}_{4}$ solution were sown in plastic pots filled with soil. The osmo-primed seeds were laid in completely randomized design. Drought was maintained in three levels i.e. control 100\% FC, 70\% FC and 35\% FC. After one month of drought treatment $50 \%$ plant replicates were sampled for measurement of seed germination characteristics, growth attributes and chlorophyll pigments and left the remaining $50 \%$ plants for further growth. Drought was maintained till the crop ripening and at the end yield attributes were recorded. Water deficit stress decreased the germination rate, fresh and dry weight of root and shoot, total chlorophyll, chlorophyll a, chlorophyll b and carotenoid in all chickpea varieties. However, the seed priming with $\mathrm{ZnSO}_{4}$ improved the growth conditions of the plants. $\mathrm{ZnSO}_{4}$ seed priming also caused early germination than in non-primed. Overall, the results showed that CM 2008 and FG 0902 chickpea varieties were more drought tolerant than others while there was wide variation among chickpea varieties in response to seed priming with $\mathrm{ZnSO}_{4}$ solution. Overall, $\mathrm{ZnSO}_{4}$ seed priming alleviate the drought effect by enhancing the growth condition of plants and in turn the yield of chickpea cultivars.
\end{abstract}

Keywords: chickpea, drought, seed priming, yield, zinc

\section{Introduction}

Cicer arietinum L. is one of the important grain crops of developed and developing countries in terms of food and nutrition. It is included in the major legume plant and is on $3^{\text {rd }}$ place after beans and peas with accounting 10.1 million tons yield production in the world (FAO, 2015). These three pulses (beans, peas, and chickpeas) account for about $70 \%$ of global pulse production with chickpea accounting for approximately $17 \%$ of the total annually (Muehlbauer and Sarker, 2017). It is a rich source of proteins (23\%), carbohydrates (64\%) and dietary fibers (19\%) and with small amount of cholesterol and fats (Chibbar et al., 2010). Calcium, zinc, magnesium, phosphate, manganese, iron and vitamin K are also present in chickpea (Wood and Grusak, 2007). Water stress is found to be a major growth and yield limiting factor in chickpea around the world (Manjunath and Dhanoji, 2010).

Drought is a period of dry climate conditions which results in water deficit in soil and consequently in plants. Drought areas face below-average rainfall and scarcity of water supply which can last for months to years (Yadav et al., 2006; Toker et al., 2007). 
Plants growth and reproduction is negatively affected by low water availability (Chen et al., 2012). In plants, photosynthesis, metabolic pathways and other physiological processes may cease due to intensive drought conditions (Jaleel et al., 2008). Various mineral nutrients depend on moisture of the soil to move through the soil texture and be absorbed by plants (Taiz and Zeiger, 2006). Under water deficit conditions, due to slow mineral diffusion and slow rate of water movement, roots are incapable to absorb several nutrients from the soil (Dubey and Pessarakli, 2001). Plants show different adaptive mechanisms against environmental stresses (Kanwal et al., 2018).

Different macro and micro elements are necessary for normal plant development. In which, micronutrients are chemical compounds required in small quantities but very essential for plant development and growth. Zinc is one of the key micronutrient for plants. Its deficiency in agricultural soils is common in all over the developed and developing countries especially in drought areas (Harris et al., 2007a; Dobermann and Fairhurst, 2000). It is reported that growth and yield of various crops, i.e. maize, wheat, rice etc. is affected by $\mathrm{Zn}$ deficiency (Harris et al., 2005, 2007a). The effects of $\mathrm{Zn}$ deficiency on plants can be overcome by external application of $\mathrm{Zn}$. It can be applied in the form of fertilizer, spray and priming etc. (Singh, 2007; Farooq et al., 2009). However, seed priming is an easy and cost effective way of $\mathrm{Zn}$ application on plants (Salehi Arjmand et al., 2014). It is an extensively used commercial process for many crops that speed up the germination rate and enhances seedling consistency in various crops by triggering the certain physiological processes responsible for seed germination (Halmer, 2003). Seed priming with $\mathrm{Zn}$ solution enhanced the seed germination and seedling vigor index in Hordeum vulgare (barley) and Cicer arietinum (chickpea) as well as results in the maximum economic yield for Triticum aestivum (wheat) and Zea mays (maize) (Harris et al., 2007c, 2008).

In Pakistan, chickpea is traditionally grown on sandy soils of arid and semi-arid regions. Due to increasing pollution and change in climate water scarcity is a persistent phenomenon in Pakistan and mainly different areas of Baluchistan, Sindh and Southern Punjab are drought affected regions of Pakistan in agricultural point of view. In these regions agriculture and ecosystem are greatly affected by drought conditions (Setter et al., 2001; Reddy et al., 2004). Drought is one of the important limiting factors for chickpea growth and yield in these areas because economic factors and sandy soils do not allow artificial irrigation of chickpea crop. Zn deficiency also prevails in chickpea growing areas of Pakistan (Shah et al., 2007). To overcome the adverse effects of $\mathrm{Zn}$ deficiency on plants, seed priming with Zinc Sulphate $\left(\mathrm{ZnSO}_{4}\right)$ can be an effective way to improve the germination, growth and in turn yield of the crop (Harris et al., 2007b, 2008) and may be helpful in alleviating the adverse effects of drought. However, literature evidenced a little information about influence of $\mathrm{ZnSO}_{4}$ seed priming in enhancing the growth condition and production of chickpea. So, the present study was aimed to assess the role of $\mathrm{ZnSO}_{4}$ seed priming in enhancement of chickpea growth and yield under drought conditions.

\section{Materials and methods}

\section{Description of the study site}

Experiment was performed in research field area of Government College Women University, Faisalabad, Pakistan with day length of $11 \mathrm{~h}$ (light period) night length of $13 \mathrm{~h}$ (dark period) in 2015. The experimental time period was started from September 
2015 and final yield was harvested in mid of April 2016. The approximate temperature crop faced was $28-34^{\circ} \mathrm{C}$. Geographically research field is located at $31^{\circ} 42$ ' latitude and $73^{\circ} 08^{\prime}$ longitude and it is situated at an elevation of 186 meters above sea level. Three drought levels (100-control, $70 \%$ and 35\% field capacity) were maintained during the whole experiment.

\section{Experimental design and crop establishment}

Experiment was laid in completely randomized design and the treatments were analyzed in $4 \times 2 \times 3$ factorial scheme with three replicates, in a total of 72 pots. Four chickpea cultivars (CM 2008, FG 0902, DO 75-09 and Pb 2008) were studied with two different seed priming treatments. The seeds of chickpea collected from Nuclear Institute for Agriculture and Biology (NIAB), Faisalabad, Pakistan. We took four chickpea cultivars, declared as drought resistant by NIAB.

The 72 pots were equally divided in to two sets (each set having 36 pots). One set of 36 pots with seeds primed with $\mathrm{ZnSO}_{4}$ and other set of 36 pots having seeds primed with distilled water for $12 \mathrm{~h}$. Ten seeds were sown in each plastic pot of $25 \mathrm{~cm}$ of diameter and $28 \mathrm{~cm}$ length. Each pot was filled with $8 \mathrm{~kg}$ of soil mixture with soil + sand + compost in 1:1:1 ratio (Fig. 1).

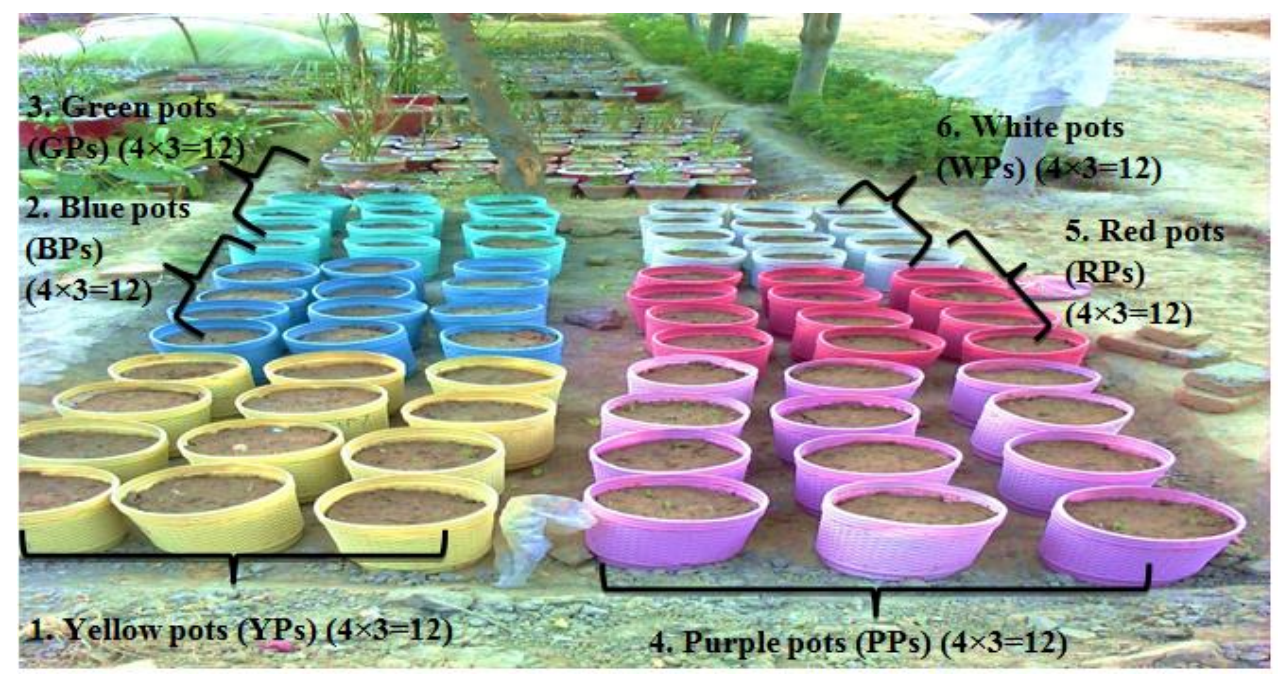

Figure 1. YPs $=$ Controlled $(100 \% \mathrm{FC}+$ distilled water priming $) B P s=70 \% \mathrm{FC}+$ distilled water priming, $G P s=35 \% \mathrm{FC}+$ distilled water priming, $\mathrm{PPs}=100 \% \mathrm{FC}+\mathrm{ZnSO}_{4}$ Priming, $R P s=70 \% \mathrm{FC}+\mathrm{ZnSO}_{4}$ Priming, WPs $=35 \% \mathrm{FC}+\mathrm{ZnSO}_{4}$ Priming

Field capacity was determined by the estimation of the total moisture contents of the soil by following formula (Khakwani et al., 2012) to maintain the three drought levels.

\section{Field Capacity $=$ saturation percentage $/ 2$}

The research area was covered from upper side in order to avoid rainfall water to fall on pots. Thus the drought levels were under controlled conditions.

\section{Observations recorded}


After thirty days of germination, data for the following attributes was noted and at the crop ripening yield was recorded.

\section{Seed germination characteristics}

The recorded germination attributes include time of germination, number of seeds germinated, percentage germination, rate of germination and seed vigor index. Root and shoot length and fresh and dry weight of seedlings were also measured. These characters were assessed based on formulae (Seyedi et al., 2012; Goodi and Sharifzadeh, 2006) given below:

$$
\begin{gathered}
\text { Germination rate }=\frac{\sum n i}{\sum n i d i} \\
(n i=\text { number of seeds germinated, } \mathrm{di}=\text { days of germination }) \\
\text { Seed vigor index }=\frac{\text { (Shoot length }+ \text { Root length }) \times \% \text { Germination }}{100}
\end{gathered}
$$

\section{Growth attributes}

Fresh shoot weight (FSW) and fresh root weight (FRW) was measured by using electrical balance. Prior to determination of fresh SW and RW, shoots and roots were washed with distilled water and then dried with towel. After that root length (RL) and shoot length (SL) were measured by using ruler. Then sample plants were oven dried for $48 \mathrm{~h}$ at $70{ }^{\circ} \mathrm{C}$. After drying the samples their dry shoot weight (DSW) and dry root weight (DRW) were measured by using electrical balance.

\section{Photosynthetic pigments}

Chlorophyll pigments including Chlorophyll a, b, Chlorophyll a/b ratio, total chlorophyll content and carotenoids content were measured and calculated according to Lichtenthaler (1987). Concisely, fresh leaves were homogenized with cold acetone $(80 \% \mathrm{v} / \mathrm{v})$, and then centrifuged for 10 minutes at $5,000 \mathrm{rpm} \times \mathrm{g}$. The absorbance of each supernatant was read at 663,645 and $480 \mathrm{~nm}$.

\section{Yield attribute}

Yield attributes including number of pods per plant and total yield were recorded.

\section{Statistical analysis}

To analyze the data and draw graphs MSTAT and Microsoft Excel were used. MSTAT statistical software was used for the Analysis Of Variance. Wherever, F-test exhibited significant differences between means. Least Significant Differences (LSD) test was applied to compare the means at the 0.05 level of probability (Steel and Torrie, 1996).

\section{Results}

In present research, the influences of $\mathrm{ZnSO}_{4}(0.05 \% \mathrm{w} / \mathrm{v})$ seed priming on four chickpea cultivars were evaluated on the basis of seed germination parameters, growth 
attributes, chlorophyll pigments and yield attributes under controlled and drought conditions.

\section{Seed germination parameters}

Seed germination characters such as germination percentage, rate of germination and seed vigor index (SVI) gave the minimum values under drought conditions in all chickpea cultivars as compared to control. While, seeds primed with $\mathrm{ZnSO}_{4}$ exhibited significant $(\mathrm{P}<.05 \%)$ increase in these germination characters as compared to seeds primed with distilled water in all four chickpea cultivars under controlled as well as under drought stress levels. However, CM 2008 and FG 0902 cultivars gave more values of germination percentage, rate of germination and SVI than other cultivars in both conditions i.e. seeds primed with $\mathrm{ZnSO}_{4}$ and with distilled water (Fig. 2, Table 1).

Table 1. Germination percentage (Ger. \%), germination rate (Ger. Rate), seed vigor index (SVI), chlorophyll a (Chl. a), chlorophyll b (Chl. b), chlorophyll a/b ratio (Chl. a/b ratio), total chlorophyll (Total Chl), carotenoids contents of four chickpea cultivars from seeds primed with $\mathrm{ZnSO}_{4}$ and distilled water and grown in moisture conditions in field capacity and drought stressed

\begin{tabular}{c|c|c|c|c|c}
\hline Source of variation & df & Ger. \% & Ger. Rate & SVI & Chl. a \\
\hline Cultivars (Cvs) & 3 & $39.47 * * *$ & $39.47 * * *$ & $92.39 * * *$ & $747.14 * * *$ \\
Treatment (T) & 1 & $263.16 * * *$ & $263.16 * * *$ & $312.60 * * *$ & $546.78 * * *$ \\
Drought (D) & 2 & $86.63 * * *$ & $86.63 * * *$ & $460.61 * * *$ & $198.58 * * *$ \\
Cvs x T & 3 & $4 *$ & $4 *$ & $8.62 * * *$ & $40.52 * * *$ \\
Cvs x D & 6 & $0.74 \mathrm{~ns}$ & $0.74 \mathrm{~ns}$ & $8.03 * * *$ & $88.24 * * *$ \\
T x D & 2 & $7.68 * *$ & $7.68 * *$ & $26.86 * * *$ & $38.99 * * *$ \\
Cvs x T x D & 6 & $0.11 \mathrm{~ns}$ & $0.11 \mathrm{~ns}$ & $0.40 \mathrm{~ns}$ & $9.05 * * *$ \\
Error & 48 & 52.78 & 0.01 & 53.38 & 6.16 \\
\hline Source of variation & $\mathbf{d f}$ & Chl. b & Chl. a/b ratio & Total Chl. & Carotenoids \\
\hline Cultivars (Cvs) & 3 & $898.22 * * *$ & $369.27 * * *$ & $1023.75 * * *$ & $16.36 * * *$ \\
Treatment (T) & 1 & $730.59 * * *$ & $125.42 * * *$ & $1535.86 * * *$ & $57.92 * * *$ \\
Drought (D) & 2 & $384.98 * * *$ & $232.71 * * *$ & $226.97 * * *$ & $19.37 * * *$ \\
Cvs x T & 3 & $40.57 * * *$ & $5.05 * *$ & $342.39 * * *$ & $1.08 \mathrm{~ns}$ \\
Cvs x D & 6 & $32.76 * * *$ & $60.55 * * *$ & $95.59 * * *$ & $3.26 * *$ \\
T x D & 2 & $15.74 * * *$ & $15.20 * * *$ & $5.89 * *$ & $8.50 * * *$ \\
Cvs x T x D & 6 & $2.22 \mathrm{~ns}$ & $3.33 * *$ & $4.47 * *$ & $0.75 \mathrm{~ns}$ \\
Error & 48 & 6.22 & 0.04 & 0.001 & 5.87 \\
\hline
\end{tabular}

$*, * *$ and $* * *=$ significant at $0.05,0.01$, and 0.001 levels, respectively; $\mathrm{ns}=$ non-significant $\mathrm{df}=$ degree of freedom 

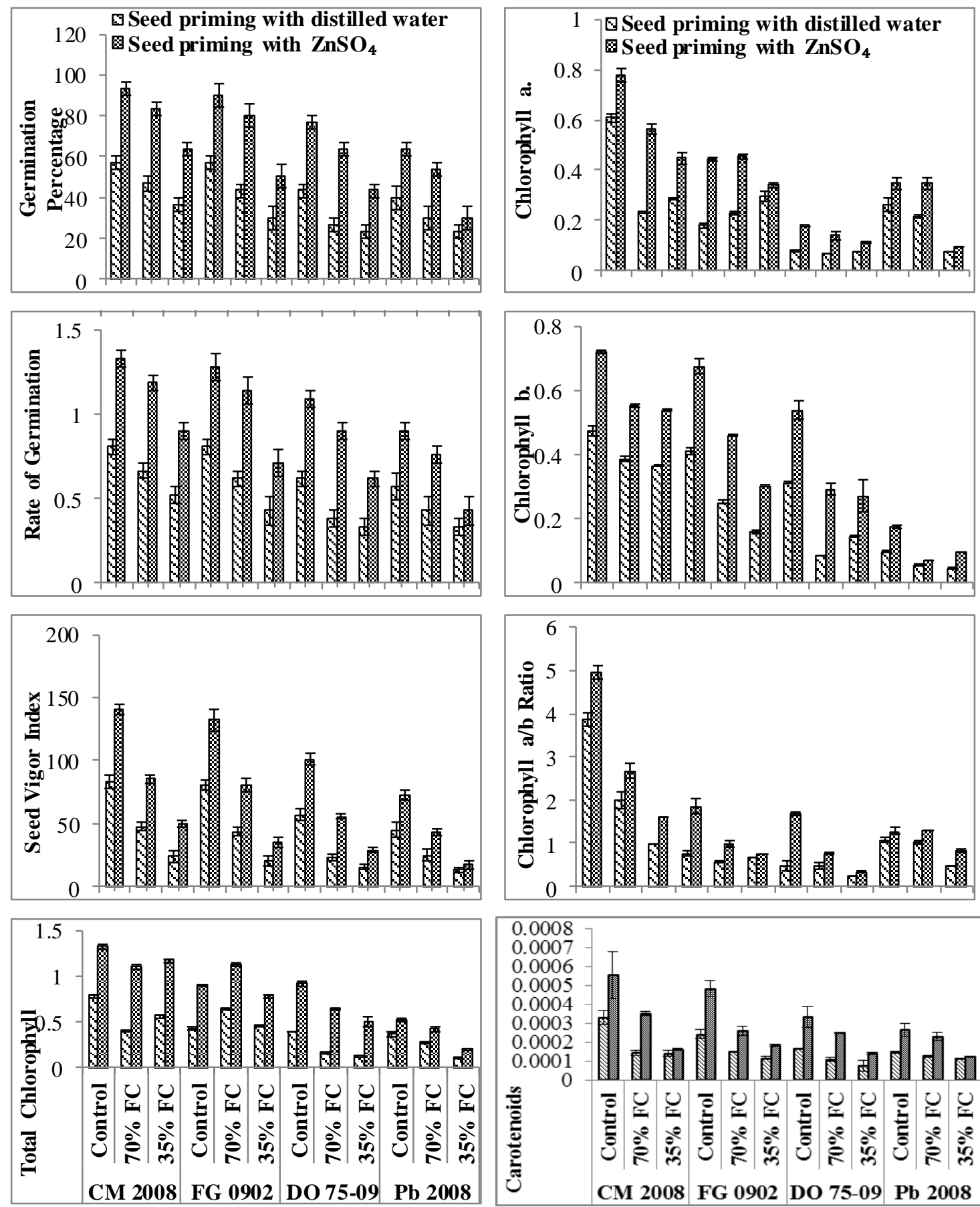

Figure 2. Seed germination and photosynthetic pigments characteristics of four chickpea cultivars raised from seeds primed with $\mathrm{ZnSO} 4$ and distilled water as influenced under drought (Control, $70 \% F C$ and $35 \% F C$ ) stress (Mean \pm S.E.)

\section{Photosynthetic pigments}

With increasing drought levels, in all cultivars gave the minimum values of chlorophyll a, chlorophyll $\mathrm{b}$, total chlorophyll content, chlorophyll $\mathrm{a} / \mathrm{b}$ ratio and carotenoid content was recorded. While, these attributes when measured in plants raised from $\mathrm{ZnSO}_{4}$ primed seeds of all four cultivars gave more values as compared to distilled 
water primed seeds under all three field capacities (100\%, $70 \%$ and $35 \%$ FC). Among all cultivars, $\mathrm{Pb} 2008$ exhibited slight increase in values of Chlorophyll a and Chlorophyll b with $\mathrm{ZnSO}_{4}$ seed priming treatment at $35 \% \mathrm{FC}$ and $70 \% \mathrm{FC}$ respectively. While, DO 75-09 cultivar showed minute increase in the values of carotenoid content at $70 \% \mathrm{FC}$ and $35 \% \mathrm{FC}$ with $\mathrm{ZnSO}_{4}$ seed priming treatment than with distilled water. However, CM 2008 and FG 0902 cultivars showed highly significant $(\mathrm{P}<.05 \%)$ and gave more values in all chlorophyll pigment parameters and carotenoid content with $\mathrm{ZnSO}_{4}$ seed priming than seeds primed with distilled water at all drought levels than that of other two cultivars (Fig. 2, Table 1).

\section{Growth attributes}

Minimum values were recorded in root length (RL) and shoot length (SL), fresh shoot (FSW) and fresh root weight (FRW), dry root (DRW) and dry shoot weight (DSW) under drought stress (70\% FC and 35\% FC) in all cultivars but seed priming with $\mathrm{ZnSO}_{4}(0.05 \% \mathrm{w} / \mathrm{v})$ caused a significant $(\mathrm{P}<.05 \%)$ increase in these growth attributes under all levels of field capacities $(100 \% \mathrm{FC}, 70 \% \mathrm{FC}$ and $35 \% \mathrm{FC})$ than in plants raised from seeds primed with distilled water. However, CM 2008 and FG 0902 cultivars treated with $\mathrm{ZnSO}_{4}$ showed higher values of RL and SL as compared to seeds primed with distilled water under all drought conditions $(100 \%, 70 \%$ and $35 \%$ field capacity) than other two cultivars (Fig. 3, Table 2).

Table 2. Shoot length (SL), root length ( $R L)$, shoot fresh weight (SFW), shoot dry weight $(S D W)$, root fresh weight $(R F W)$, root dry weight $(R D W)$, pods per plant and total yield of four chickpea cultivars from seeds primed with $\mathrm{ZnSO}_{4}$ and distilled water and grown in moisture conditions in field capacity and drought stressed

\begin{tabular}{|c|c|c|c|c|c|}
\hline Source of variation & df & SL & RL & FSW & DSW \\
\hline Cultivars (Cvs) & 3 & $1285.69 * * *$ & $8338.13 * * *$ & $3396.11 * * *$ & $5559.96 * * *$ \\
\hline Treatment $(\mathrm{T})$ & 1 & $1403.62 * * *$ & $2152.22 * * *$ & $2609.36 * * *$ & $7955.87 * * *$ \\
\hline Drought (D) & 2 & $2821.98 * * *$ & $94461.47 * * *$ & $29357.39 * * *$ & $123396.04^{* * *}$ \\
\hline Cvs $\mathrm{x} T$ & 3 & $11.42 * * *$ & $38.79 * * *$ & $146.55^{* * *}$ & $118.001 * * *$ \\
\hline Cvs $x \mathrm{D}$ & 6 & $107.79 * * *$ & $954.26^{* * *}$ & $22.96 * * *$ & $1000.45^{* * *}$ \\
\hline $\mathrm{T} \times \mathrm{D}$ & 2 & $1.47 \mathrm{~ns}$ & $82.67 * * *$ & $46.97 * * *$ & $466.43^{* * *}$ \\
\hline Cvs $x \mathrm{~T}$ x D & 6 & $12.09 * * *$ & $74.19 * * *$ & $3.69 * *$ & $116.49 * * *$ \\
\hline Error & 48 & 0.215 & 0.22 & 0.02 & 3.29 \\
\hline Source of variation & df & FRW & DRW & Pods/Plant & Total Yield \\
\hline Cultivars (Cvs) & 3 & $5660.24 * * *$ & $1143.91 * * *$ & $51.29 * * *$ & $427.75 * * *$ \\
\hline Treatment $(\mathrm{T})$ & 1 & $1777.44 * * *$ & $2848.88 * * *$ & $99.19 * * *$ & $1566.97 * * *$ \\
\hline Drought (D) & 2 & $33240.3 * * *$ & $3906.86^{* * *}$ & $33.58 * * *$ & $427.75 * * *$ \\
\hline Cvs $\mathrm{x} T$ & 3 & $23.45^{* * *}$ & $292.86 * * *$ & $2.08 \mathrm{~ns}$ & $102.67 * * *$ \\
\hline Cvs $\mathrm{x} D$ & 6 & $797.87 * * *$ & $155.09 * * *$ & $1.19 \mathrm{~ns}$ & $53.33 * * *$ \\
\hline $\mathrm{T} \times \mathrm{D}$ & 2 & $371.18^{* * *}$ & $484.67 * * *$ & $4 *$ & $122.26^{* * *}$ \\
\hline Cvs $x$ T x D & 6 & $30.32 * * *$ & $20.23 * * *$ & $0.56 \mathrm{~ns}$ & $13.70 * * *$ \\
\hline Error & 48 & 5.71 & 1.69 & 0.67 & 0.03 \\
\hline
\end{tabular}

$*, * *$ and $* * *=$ significant at $0.05,0.01$, and 0.001 levels, respectively; $\mathrm{ns}=$ non-significant; $\mathrm{df}=$ degree of freedom 

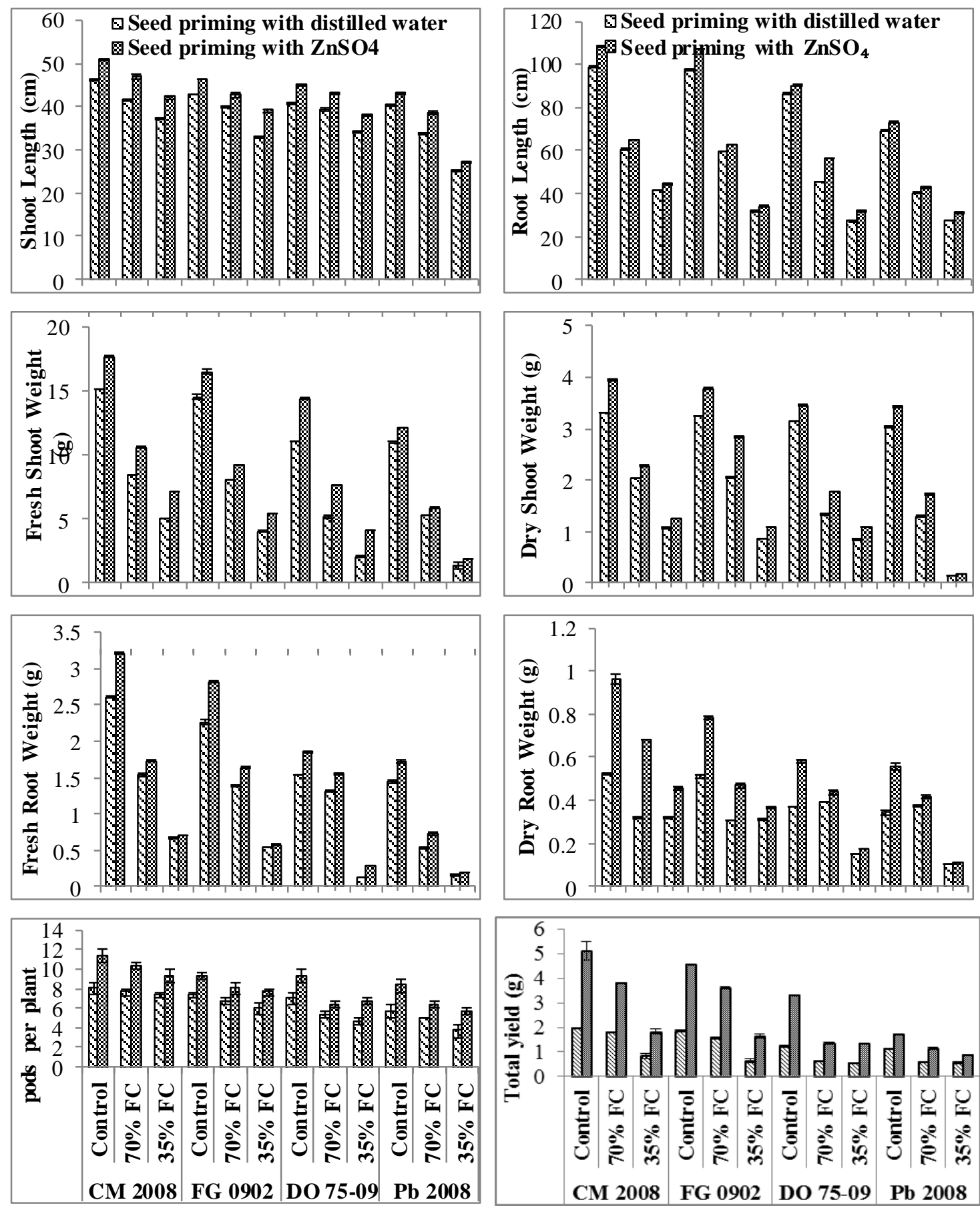

Figure 3. Growth and yield attributes of four chickpea cultivars raised from seeds primed with $\mathrm{ZnSO}_{4}$ and distilled water as influenced under drought (Control, 70\%FC and 35\%FC) stress

(Mean \pm S.E.)

Similarly, CM 2008 and FG 0902 cultivars showed the higher FSW and FRW values of seeds primed with $\mathrm{ZnSO}_{4}$ under all drought levels as compared to seeds primed with distilled water. Seed priming with $\mathrm{ZnSO}_{4}$ caused a slight increase in FSW and FRW of DO 75-09 under controlled and 70\% drought condition. But DO 75-09 cultivar showed maxim values under controlled conditions while showed a slight difference of FSW and 
FRW in $\mathrm{ZnSO}_{4}$ primed and distilled water primed seeds under drought of $70 \%$ and $35 \%$ FC. DSW and DRW were also high significantly $(\mathrm{P}<.05 \%)$ in plants raised from seeds primed with $\mathrm{ZnSO}_{4}$ of all cultivars under controlled and water deficit conditions than in seeds primed with distilled water.

While, CM 2008 and FG 0902 cultivars showed higher values of DSW and DRW with treatment of $\mathrm{ZnSO}_{4}$ seed priming under control, $70 \% \mathrm{FC}$ and $35 \% \mathrm{FC}$ than in distilled water primed seeds. While, DO 75-09 and Pb 2008 cultivars showed higher values of DSW and DRW under control and $70 \% \mathrm{FC}$ but there was slight or no change under $35 \% \mathrm{FC}$ in plants rose from seeds primed with water and $\mathrm{ZnSO}_{4}$. Overall, CM 2008 and FG 0902 cultivars with $\mathrm{ZnSO}_{4}$ seed priming treatment showed higher values of these attributes (FSW, FRW, DSW and DRW) than others (Fig. 3, Table 2).

\section{Yield attributes}

Yield attributes such as number of pods per plant and yield per plant were significantly $(\mathrm{P}<.05 \%)$ decreased with increasing drought stress levels as compared to control. Whereas, the analysis of data showed that the application of $\mathrm{ZnSO}_{4}(0.05 \%$ $\mathrm{w} / \mathrm{v}$ ) as seed priming treatment increased the overall yield of all four cultivars of chickpea under all three field capacities (100\%, $70 \%$ and 35\% field capacity) as compared to plants raised from distilled water primed seeds. However, CM 2008 and FG 0902 chickpea cultivars showed more enhanced yield as compared to other cultivars in plants raised from seeds primed with $\mathrm{ZnSO}_{4}$ than that of plants raised from distilled water primed seeds under both controlled and water deficit conditions (Fig. 3, Table 2).

\section{Discussion}

Pre-sowing seed priming treatment with $\mathrm{ZnSO}_{4}$ helped the plants to respond positively under different drought levels. Plants take up zinc as a divalent cation $\left(\mathrm{Zn}^{2+}\right)$ from the soil. It is an eloquent nutrient for plant growth and development also functions as a co-factor of various enzymes such as $\mathrm{Cu}-\mathrm{Zn}$ superoxide dismutase, RNA polymerase, alcohol dehydrogenase, carbonic anhydrase, etc. (Reddy, 2006). It is an important structural, functional and regulatory co-factor of various enzymes which help to enhance the activity of biochemical and physiological mechanisms in plants. $\mathrm{Zn}$ is an important component for the metabolism of carbohydrates and auxins, protein synthesis, etc. (Mengel et al., 2001; Broadley et al., 2007).

The results of this research showed that increased levels of drought stress caused decrease in percentage germination, rate of germination and seed vigor index of all chickpea cultivars while $\mathrm{ZnSO}_{4}$ seed priming treatment enhances the values of all these attributes under all drought levels. The decrease occurred due to low availability of water which eventually resulted in reduction in values of germination attributes. Plant mineral nutrition, yield and growth face deleterious effects of drought stress (Garg et al., 2004; Samarah et al., 2004). Grewal and Williams (2000) reported the influence of $\mathrm{Zn}$ along with soil moisture stress on different varieties of Medicago sativa $\mathrm{L}$. (alfalfa). They also suggested that alfalfa plants have the ability to tolerate with the excessive moisture stress as well as with water deficit conditions under adequate supply of $\mathrm{Zn}$ nutrient. While having a comparison of primed and non-primed seeds Karmore et al. (2015) reported that hydropriming treatment had significant effect on the growth of seedling than non-primed seeds. Slow rate of imbibition could be the cause of decreased seed vigour index in non-primed seeds (Fatemi, 2014). These all findings support the 
enhancement of germination characters in present study due to seed priming with $\mathrm{ZnSO}_{4}$ under all field capacities.

This study revealed that plants grown from $\mathrm{ZnSO}_{4}$ primed seeds showed increase in values of all growth attributes as compared to developed from seeds primed with distilled water. According to previous research it has been reported that in wheat plants Zn plays an effective role in production of increased dry weight (Imtiaz et al., 2003; Ozkutlu et al., 2006). Arif et al. (2005) and Ali et al. (2007) reported that seed priming treatment with $\mathrm{ZnSO}_{4}$ caused an increase in plant height. The shoot and root length are fundamental parameters, because roots absorb water and essential nutrients from the soil by having direct contact with it. Whereas, shoot transport the nutrients as well as water to the rest of the plant body. While having comparison with results provided on seed priming effect on growth parameters of maize, it has been revealed that $\mathrm{ZnSO}_{4}$ seed priming treatment influenced positively shoot and root length of maize and pulses (Ambika and Balakrishnan, 2015).

An increased root length of plants grown from seeds primed with $\mathrm{ZnSO}_{4}$ as compared to distilled water primed seeds could be the result of extensibility in cell wall of the embryo. Seed priming treatment caused increase in the activity of ROS (reactive oxygen species) scavenging enzymes in order to enhance the plant strength and viability (Ambika and Balakrishnan, 2015). Same researcher also reported that seed priming with $\mathrm{ZnSO}_{4}$ solution decreased the resistance mechanism of endosperm envelope against growth permitting turgor threshold for germination as compared to non-primed seeds resulting increased shoot and root length. In another study, Harris et al. (2007a) reported that primed seeds show early seed vigour and significantly enhanced shoot and root length, as a result heavier seedlings production occur due to increased activity of $\alpha$ amylase enzyme.

The results of this study showed that all chickpea cultivars primed with $\mathrm{ZnSO}_{4}$ gave higher values of all chlorophyll pigment as compared to treated with distilled water under all drought levels. The results presented are the agreement with the findings of Nyachiro et al. (2001), who reported that in six cultivars of wheat the water deficit, caused a significant decrease in the concentration of chlorophyll a and b. it has also been reported that unchanged or decreased chlorophyll content could either be the result of severe drought or prolonged drought conditions (Mafakheri et al., 2010). The absorption of excess energy in the photosynthetic apparatus may be the main cause of ROS in large concentration it could be escaped by degrading the pigments responsible for their absorption (Herbinger et al., 2002). All genotypes showed decreased values of total chlorophyll content but the reduction was very low in tolerant cultivars (Deng et al., 2003) as in CM 2008 and FG 0902 chickpea cultivars in present study.

Carotenoids have a critical role as photoprotective compounds by quenching triplet and singlet oxygen derived from excess light energy, thus limiting membrane damage (Pogson et al., 2006; Tas, 2007). In present study, the higher accumulation of carotenoid in CM 2008 and FG 0902 chickpea cultivars under water stress could result in a positive effect on plant growth by affecting relative water content as reported by Talebi et al. (2013), Franca et al. (2000) and Gunes et al. (2008). However, the more enhanced increase in chlorophyll and carotenoid content in CM 2008 and FG 0902 chickpea cultivars raised from seeds primed with zinc as compared to distilled water primed seeds under control and drought conditions may be due to $\mathrm{Zn}$ which functions as a structural, functional and catalytic component of enzymes, proteins and also a co-factor for normal growth and development of biosynthetic pigments (Samreen et al., 2013). 
Yield attributes were significantly increased in all chickpea cultivars grown from seeds primed with $(0.05 \% \mathrm{w} / \mathrm{v}) \mathrm{ZnSO}_{4}$ solution as compared to grown from distilled water primed seeds under controlled and drought levels. Drought is one of the greatest yield limiting factors in agriculture (Reddy et al., 2004). Researcher, Harris et al. (2007b) suggested that seed priming with Zn caused a significant increase in weight of grains and total yield. Furthermore, priming treatment induced an increase in grain weight, total yield and plays a fundamental role in availability of $\mathrm{Zn}$ as a nutrient in diets of human and animals (Harris et al., 2007b). It is agreement with the results of present research. However, CM 2008 and FG 0902 chickpea cultivars showed more enhanced yield as compared to other cultivars.

\section{Conclusion}

From all above discussion, it can be inferred that drought stress adversely affected all the parameters studied in present research such as germination attributes, shoot and root length, shoot and root fresh and dry weights, photosynthetic pigments and yield characteristics were decreased under water deficit conditions in both sets of plants raised from seeds primed with $\mathrm{ZnSO}_{4}(0.05 \%)$ solution and with distilled water. However, $\mathrm{ZnSO}_{4}$ seed priming showed increased values for all mentioned attributes under control as well as under stressed environment in all chickpea cultivars. While, the results of different parameters showed that cultivars CM 2008 and FG 0902 were more tolerant to drought stress as compared to other cultivars. It can be concluded that $\mathrm{ZnSO}_{4}$ seed priming has positive effect on plant growth and development and could be an effective mean of getting better yield under stressed as well as non-stressed environments. Thus, seed priming treatment of $\mathrm{Zn}$ micronutrient can be helpful for researchers to increase the crop resistance against abiotic stresses especially drought stress. However, it is also helpful to increase the yield of crops under drought stress as it increases the root capability to up take water and mineral nutrients from the soil.

Acknowledgements. The first and second authors greatly acknowledge the funding from Higher Education Commission (HEC) of Pakistan as this research work is a part of HEC funded research project entitled "Evaluation of drought tolerance in chickpea (Cicer arietinum L.) raised from seeds treated with $\mathrm{ZnSO}_{4}$ " (SRGP 466). The results of this research paper are included as research work of M.Phil studies of Miss. Ammara Mahmood. I would like to acknowledge Miss Amna Mahmood for her help in literature search, Tariq Mahmud Shah for providing seeds of chickpea varieties for study and Ali Noman for guiding me in paper write up.

Author contributions. This work was carried out in collaboration between all authors. 'Author Ammara Mahmood' designed the study, wrote the manuscript, managed the field work, practical analysis and wrote the protocol. 'Author Hina Kanwal' supervised the whole research work from the beginning to finish and also checked the final draft. 'Author Noreen Akhter and Aisha Ilyas' helped in field work and data collection. 'Author Abida Kausar' being member of my supervisory committee helped and guided me in laboratory work. 'Author Madiha Ilyas' helped to check the nutrient value of yield. 'Author Zaib UN Nisa' was paper write up checker. 'Author Hafsa Khalid' managed the literature searches. All authors read, checked and approved the final manuscript. 


\section{REFERENCES}

[1] Ali, S., Arif, M., Gul, R., Khan, A., Shah, S. S., Ali. I. (2007): Improving maize seed emergence and early seedling growth through water soaking. - Scientific Khyber 19: 173-177.

[2] Ambika, S., Balakrishnan, K. (2015): Enhancing germination and seedling vigour in cluster bean by organic priming. - Scientific Research and Essays 10: 298-301.

[3] Arif, M., Ali, S., Shah, A., Javed, N., Rashid, A. (2005): Seed priming maize for improving emergence and seedling growth. - Sarhad Journal of Agriculture 21: 539-543.

[4] Broadley, M. R., White, P. J., Hammond, J. P., Zelko, I., Lux, A. (2007): Zinc in plants. New Phytologist 173: 677-702.

[5] Chen, J., Xu, W., Velten, J., Xin, Z., Stout, J. (2012): Characterization of maize inbred lines for drought and heat tolerance. - Journal of Soil and Water Conservation 67: 354364.

[6] Chibbar, R. N., Ambigaipalan, P., Hoover, R. (2010): Molecular diversity in pulse seed starch and complex carbohydrates and its role in human nutrition and health. - Cereal Chemistry Journal 87: 342-352.

[7] Deng, X., Hu, Z. A., Wang, H. X., Wen, X. G., Kuang, T. Y. (2003): A comparison of photosynthetic apparatus of the detached leaves of the resurrection plant Boea hygrometrica with its non-tolerant relative Chirita heterotrichia in response to dehydration and rehydration. - Plant Science 165: 851-861.

[8] Dobermann, A., Fairhurst, T. (2000): Rice: Nutrient Disorders and Nutrient Management. Handbook Series. - Potash and Phosphate Institute (PPI), Potash and Phosphate Institute of Canada (PPIC) and International Rice Research Institute.

[9] Dubey, R. S., Pessarakli, M. (2001): Physiological Mechanisms of Nitrogen Absorption and Assimilation in Plants under Stressful Conditions. - In: Passarakli, M. (ed.) Handbook of Plant and Crop Physiology ( $2^{\text {nd }}$ ed.) Marcel Dekker Inc, New York.

[10] Farooq, M., Basra, S. M. A., Wahid, A., Khaliq, A., Kobayashi, N. (2009): Rice Seed Invigoration. - In: Lichtfouse, E. (ed.) Sustainable Agriculture Reviews. Springer, The Netherlands.

[11] Fatemi, S. N. (2014): Germination and seedling growth in primed seeds of sunflower under water stress. - Annual Research and Review in Biology 4: 3459-3469.

[12] Food and Agriculture Organization of the United Nations (FAO) (2007): On-Line Crop Database. - http://ecocrop.fao.org/ecocrop/srv/en/cropSearchForm.

[13] Franca, M. G. C., Thi, A. T. P., Pimental, C., Rossiello, R. O. P., Fodil, Y. Z., Laffray, D. (2000): Differences in growth and water relations among Phaseolus vulgaris cultivars in response to induced drought stress. - Environmental and Experimental Botany 43: 227237.

[14] Garg, B. K., Burman, U., Kathju, S. (2004): The influence of phosphorus nutrition on the physiological response of moth bean genotypes to drought. - Journal of Plant Nutrition and Soil Science 167: 503-508.

[15] Goodi, M., Sharifzadeh, F. (2006): Evaluation effect of hydropriming in barley difference cultivars. - Magzine Biaban 11: 99-109.

[16] Grewal, H. S., Williams, R. (2000): Zinc nutrition affects alfalfa responses to water stress and excessive moisture. - Journal of Plant Nutrition 23: 949-962.

[17] Gunes, A., Adak, A., Inal, M. S., Bagci, E. G., Cicek, N., Eraslan, F. (2008): Effect of drought stress implemented at pre- or post-anthesis stage some physiological as screening criteria in chickpea cultivars. - Russian Journal of Plant Physiology 55: 59-67.

[18] Halmer, P. (2003): Methods to Improve Seed Performance. - In: Benech-Arnold, R. L., Sanchez, R. A. (ed.) Seed Physiology, Applications to Agriculture. Food Product Press, New York.

[19] Harris, D., Rashid, A., Arif, M., Yunas, M. (2005): Alleviating Micronutrient Deficiencies in Alkaline Soils of the North-West Frontier Province of Pakistan: On-Farm 
Seed Priming with Zinc in Wheat and Chickpea. - In: Andersen, P., Tuladhar, J. K., Karki, K. B., Maskey, S. L. (eds.) Micronutrients in South and South East Asia. ICIMOD, Kathmandu.

[20] Harris, D., Rashid, A., Miraj, G., Arif, M., Shah, H. (2007a): On-farm seed priming with zinc sulphate solution, a cost-effective way to increase the maize yields of resource poor farmers. - Field Crops Research 110: 119-127.

[21] Harris, D., Rashid, A., Miraj, G., Arif, M. Shah, H. (2007b): Priming seeds with zinc sulphate solution increases yields of maize (Zea mays L.) on zinc-deficient soils. - Field Crops Research 102: 119-127.

[22] Harris, D., Rashid, G., Miraj, A., Arif, M., Yunas, M. (2007c): On-farm' seed priming with zinc in chickpea and wheat in Pakistan. - Plant and Soil 306: 3-10.

[23] Harris, D., Rashid, A., Miraj, G., Arif, M. Yunas, M. (2008): On-farm seed priming with zinc in chickpea and wheat in Pakistan. - Plant and Soil 306: 03-10.

[24] Herbinger, K., Tausz, M., Wonisch, A., Soja, G., Sorger, A., Grill, D. (2002): Complex interactive effects of drought and ozone stress on the antioxidant defense systems of two wheat cultivars. - Plant Physiology and Biochemistry 40: 691-696.

[25] Imtiaz, M., Alloway, B. J., Shah, K. H., Siddique, S. H., Memon, M. Y., Aslam, M., Khan, P. (2003): Zinc nutritious of wheat: 1: Growth and zinc uptake. - Asian Journal of Plant Sciences 2: 152-155.

[26] Jaleel, C. A., Manivannan, P., Lakshmanan, G. M. A., Gomathinayagam, M., Panneerselvam, R. (2008): Alterations in morphological parameters and photosynthetic pigment responses of Catharanthus roseus under soil water deficits. - Colloids and Surfaces B: Biointerfaces 61: 298-303.

[27] Kanwal, H., Hameed, M., Akhter, N., Ilyas, A., Mahmood, A., Noreen, N. (2018): Ecological and taxonomic significance of root anatomy in some species and cultivars of genus Canna L. - International Journal of Agricultural and Environmental Research 5(1): $128-137$.

[28] Karmore, V. J. Tomar, G. S. (2015): Effects of seed priming methods on germination and seedling development of winter maize (Zea mays L.). - Advance Research Journal of Crop improvement 6: 88-93.

[29] Khakwani, A. A., Dennett, M. D., Munir, M., Baloch, M. S. (2012): Wheat yield response to physiological limitations under water stress condition. - Journal of Animal and Plant Sciences 22: 773-780.

[30] Lichtenthaler, H. K. (1987): Chlorophylls and carotenoids: Pigments of photosynthetic membranes. - Methods in Enzymology 148: 350-382.

[31] Mafakheri, A., Siosemardeh, A., Bahramnejad, B., Struik, P. C., Sohrabi, Y. (2010): Effect of drought stress on yield, proline and chlorophyll contents in three chickpea cultivar. - Australian Journal of Crop Science 4: 580-585.

[32] Mengel, K., Kirkby, E. A., Kosegarten, H., Appel, T. (2001): Principles of Plant Nutrition. - Kluwer Academic Publishers, Dordrecht.

[33] Manjunath., B. L., Dhanoji, M. M. (2010): Effect of seed hardening with chemicals on drought tolerance traits and yield in chickpea (Cicer arietinum L.). - Journal of Agricultural Science 3: 186-189.

[34] Nyachiro, J. M., Briggs, K. G., Hoddinott, J., Johnson-Flanagan, A. M. (2001): Chlorophyll content, chlorophyll fluorescence and water deficit in spring wheat. - Cereal Research Communications 29: 135-142.

[35] Ozkutlu, F., Torun, B., Cakmak, I. (2006): Effect of zinc humate on growth of soybean and wheat in zinc-deficient calcareous soils. - Communications in Soil Science and Plant Analysis 37: 2769-2778.

[36] Pogson, B. J., Rissler, H. M., Frank, H. A. (2006): The Roles of Carotenoid in Energy Quenching. - In: Wydrzynski, T., Satoh, K. (eds.) Photosystem II. The Water/Plastoquinone Oxidoreductase in Photosynthesis. Springer, Dordrecht. 
[37] Reddy, A. R., Chaitanya, K. V., Vivekanandan, M. (2004): Drought induced responses of photosynthesis and antioxidant metabolism in higher plants. - Journal of Plant Physiology 161: 1189-1202.

[38] Reddy, K. J. (2006): Nutrient Stress. - In: Rao, K. V. M., Raghavendra, A. S., Reddy, K. J. (ed.) Physiology and Molecular Biology of Stress Tolerance in Plants. Springer, Netherlands.

[39] Salehi Arjmand, H., Babaei, G. H., Ghorbanpour, M., Sharafi, S. (2014): Effect of zinc coated during storage on the seed quality of barley. - International Journal of Farming and Allied Sciences 3: 845-850.

[40] Samarah, N., Mullen, R., Cianzio, S. (2004): Size distribution and mineral nutrients of soybean seeds in response to drought stress. - Journal of Plant Nutrition 27: 815-835.

[41] Samreen, Humaira, T., Hamidullah, S., Saleem, U., Javid, M. (2013): Zinc effect on growth rate, chlorophyll, protein and mineral contents of hydrophonically grown mungbeans plants (Vigna radiata). - Arabian Journal of Chemistry 10: 1802-1807.

[42] Setter, T. L., Flannigan, B. A., Melkonian, J. (2001): Loss of kernel set due to water deficit and shade in maize: carbohydrate supplies, abscisic acid, and cytokinins. - Crop Science 41: 1530-1540.

[43] Seyedi, M., Hamzei, J., Fathi, H., Bourbour, A., Dadrasi, V. (2012): Effect of seed priming with zinc sulfate on germination characteristics and seedling growth of chickpea (Cicer arietinum L.) under salinity stress. - International Journal of Agriculture: Research and Review 2(3): 108-114.

[44] Shah, N. A., Aujla, K. M., Abbas, M., Mahmood, K. (2007): Economics of chickpea production in the Thal desert of Pakistan. - Pakistan Journal of Life and Social Sciences 5: 6-10.

[45] Singh, M. V. (2007): Efficiency of seed treatment for ameliorating zinc deficiency in crops. - In: Zinc Crops, Improving Crop Production and Human Health, 24-26 May, 2007, Istanbul, Turkey.

[46] Steel, R. G. D., Torrie, J. H., Dickey, D. A. (1996): Principles and Procedures of Statistics: A Biometrical Approach ( $3^{\text {rd }}$ ed.). - McGraw Hill Co, New York, USA.

[47] Taiz, L., Zeiger, E. (2006): Plant Physiology (4 ${ }^{\text {th }}$ ed). - Sinauer Associates, Massachusetts.

[48] Talebi, R., Ensafi, M. H., Baghebani, N., Karami, E., Mohammadi, K. (2013): Physiological responses of chickpea (Cicer arietinum) genotypes to drought stress. Environmental and Experimental Biology 11:9-15.

[49] Tas, S., Tas, B. (2007): Some physiological responses of drought stress in wheat genotypes with different ploidity in Turkey. - World Journal of Agricultural Sciences 3: 178-183.

[50] Toker, C., Lluch, C., Tejera, N. A., Serraj, R., Siddique, K. H. M. (2007): Abiotic Stresses. - In: Yadav, S. S., Redden, R., Chen, W., Sharma, B. (eds.) Chickpea Breeding and Management. CABI, Wallingford.

[51] Wood, J. A., Grusak, M. A. (2007): Nutritional Value of Chickpea. - In: Yadav, S. S., Redden, R., Chen, W., Sharma, B. (eds.) Chickpea Breeding and Management. CABI Publishing, Houston, USA.

[52] Yadav, S. S., Kumar, J., Yadav, S. K., Singh, S., Yadav, V. S., Turner, N. C., Redden, R. (2006): Evaluation of Helicoverpa and drought resistance in desi and kabuli chickpea. Plant Genetic Resources 4: 198-203. 